\title{
Filozofowie, skandaliści i etnarchowie - twórcy literatury czarnogórskiego oświecenia
}

\author{
Abstract \\ Philosophers, Scandalists and Ethnarchs - the Authors of the Montenegrin \\ Enlightenment Literature
}

This present article is devoted to an issue of assimilation and adaptation of the philosophical tendencies and literary patterns of the European enlightenment in Montenegrin literature which was established in $18^{\text {th }}$ century in difficult internal circumstances and during constant threat to the independence of the country. Key advocates of the rationalistic, democratic and anticlerical demands were mainly descended from the romanized Adriatic communities and obtained their education in Western Europe - transplanting into native ground the ideas of the free mind and conscience, religious tolerance, just politics, reform of the state or general education. In the context of the above-mentioned and similar categories the works of Stefan Zanović, Jovan Baljević, Katerina Radonjić and other authors were considered. The special example of taking advantage of the enlightenment paradigm are texts of the bishops and political rulers from the Petrović Njegoš dynasty - their attitude was formed through the necessity of the defence of the legal-state interest and fidelity to the Christian ethic. As a case of such a meaning of the civilizing mission in the environment of disintegrated Montenegrin tribes Petar I was presented. Especially his messages to the clan communities contain many didactic appeals which are faithful to the enlightenment vision of the man and society.

Keywords: Montenegrin literature, enlightenment, cultural tradition

Słowa kluczowe: literatura czarnogórska, oświecenie, tradycja literacka

„Epoka rozumu” w południowosłowiańskiej Czarnogórze kształtowała się w nader złożonych realiach geopolitycznych i kulturowych końca XVIII stulecia, toteż jej specyficzne ideowe konkretyzacje oraz oświeceniowe przejawy literackie wiązały się z niepospolitymi i kontrowersyjnymi postaciami. Wśród nich należy wymienić filozofa i skandalistę z Budwy uchodzącego za „obywatela Europy” 
Stefana Zanovicia (1751-1786); pierwszego doktora filozofii w tym niewielkim kraju, pochodzącego z okolic Cetinja i krążącego między Halle, Sremskimi Karłowicami oraz Rosją Jovana Stefanov(ici)a Baljevicia (1728-1769 lub 1773), identyfikowanego czasem również z tajemniczym władcą powstającego państwa Šćepanem Malim [samozwańczym carem rosyjskim Piotrem III Romanowem] zrywającym z teokratyczną tradycją rządów); a także wywodzącą się z miejscowości Njeguši Kate(a)rinę Radonjić (ok. 1700-?) - pierwszą pisarkę czarnogórską (niewykluczone, że w rzeczywistości używającego żeńskiego pseudonimu gubernatora kotorskiego Jovana Radonjicia, twórczynię bardzo postępowego w tutejszej rzeczywistości projektu świeckiego państwa urzeczywistniającego oświeceniowe idee wolności, równości oraz religijnej tolerancji. Pewne światopoglądowe składniki postawy nowoczesnego rozumnego namysłu nad światem odnaleźć też można w pisarstwie kilku władców rodzimej dynastii, którzy mieli ambicje literackie. Prekursorska była w tym względzie działalność Danila I w pierwszej połowie wieku, a zamykają ją dokonania Petara II Petrovicia Njegoša, syntezującego dorobek oświecenia z romantyzmem.

W XVIII wieku na kulturę Czarnogórców w niewielkim stopniu oddziaływały tendencje filozoficzne sformułowane przez wybitne umysły zachodniej Europy nie zyskały one wyrazistej postaci przede wszystkim z powodu cywilizacyjnego zapóźnienia, jakie powodowała przynależność tutejszych ziem w większości do Imperium Osmańskiego (terytoria wewnętrzne wraz z nieposiadającą formalnego statusu stolicą Cetinje - w sandżakach tureckich anachronizmy życia były szczególnie zauważalne), a w znacznie mniejszej tylko części do państwa Habsburgów (Boka Kotorska znajdująca się w jego ramach już na początku XIX wieku) ${ }^{1}$. Inną przyczynę niezbyt intensywnej recepcji oświeceniowej wizji człowieka, społeczeństwa, Boga, kultury i literatury stanowiła obecność utrwalonego modelu średniowiecznego prawosławia (nie tyle nawet cerkiewnego, ile ludowego - eksponującego aksjologię patriarchalno-plemienną), który zdominował większość terytorium kraju poza adriatyckim wybrzeżem, gdzie obecne były za to pewne przejawy renesansu i humanizmu o genezie romańsko-słowiańskiej. Refleks oświeceniowego racjonalizmu $\mathrm{w}$ formie nietypowej jednak zaistniał, chociaż $\mathrm{z}$ jednej strony jego elementy zaznaczyły się w twórczości pisarzy znanych lepiej na zachodzie Europy niż w ojczyźnie, z drugiej będących jednocześnie ortodoksyjnymi władykami i świeckimi władcami, co samo w sobie czyniło z nich postacie o wyjątkowym wyczuleniu na sprawy społeczne oraz religijne. Ci ostatni łączyli aktywność literacką z budzicielską działalnością polityczno-kulturalną, rzadziej stricte duszpasterską. Także ich wyobrażenie idealnego porządku świata miało eklektyczne korzenie, wywodząc się zarazem ze źródeł myśli francuskiej Woltera i Roussseau oraz rosyjskiej refleksji oświeceniowej epoki Piotra I i Katarzyny Wielkiej, jak też rodzimej ludowej kategorii zdrowego rozsądku (zdravi razum),

1 Na temat skomplikowanych uwarunkowań geopolitycznych zob. np. Ž.M. Andrijašević, Š. Rastoder, Istorija Crne Gore od najstarijih vremena do 2003, Podgorica 2006, s. 111-116; oraz D. Gil, Dylematy identyfikacyjne w obrębie serbsko-czarnogórskiej kulturosfery. Dawne i wspótczesne modele (auto)refleksji, Kraków 2019, s. 57-60. 
która na obszarach górskich stanowiła główną rękojmię przetrwania w trudnych warunkach naturalnych. Kultura etniczna niesuwerennego kraju zdominowana była przez formy folklorystyczne i poza Cetinjem, stanowiącym siedzibę biskupów-władców (w omawianym okresie-z rodu Petroviciów Njegošów), oraz kilkoma miastami nadmorskimi przekazy artystyczne wysokiego obiegu nie docierały do szerokich warstw społeczeństwa. Kulturotwórcze centra, w których edukujący się w oświeceniowych ideałach miejscowi pisarze mogli zyskiwać inspirację dla własnej twórczości, znajdowały się za granicą - między innymi w Wenecji, Padwie, Rzymie czy Halle, ale również w Anglii, Austrii, Francji, Holandii i Polsce (w przypadku Zanovicia, który jako egzotyczny awanturnik znany był w całej ówczesnej Europie, ale dziś reprezentuje w historycznoliterackiej optyce czarnogórskie właśnie oświecenie) ${ }^{2}$. Liczba dzieł popularyzujących przewodnie myśli tej formacji jest stosunkowo duża jak na wielkość populacji małej nadadriatyckiej prowincji, jednak ich wpływ koncentrował się w południowo-zachodniej jej części. Utwory te miały rozmaity poziom artystyczny oraz ładunek literackiej fikcji i były zróżnicowane gatunkowo, a ich autorzy zwykle przynajmniej przejściowo przebywali w środowisku weneckim i padewskim. Trafiały one przy tym na grunt nie całkiem jałowy, lecz przygotowany jeszcze w połowie XVIII wieku przez działalność oświatową prowadzoną między innymi w zakładanych od 1711 roku z pomocą rosyjską szkołach, w których z czasem zaczęto nauczać filozofii i wiedzy filologicznej, w szczególności retoryki. W ramach najczęściej spotykanego, choć jednak umownego, podziału ówczesnych środowisk twórczych wyodrębnić można dwie wskazane już wyżej grupy autorów: pochodzących w większości z przymorza i studiujących w państwach zachodnich „latynistów” (filozofów, prawników i teologów) oraz etnarchów z tak zwanej Starej (centralnej) Czarnogóry, których fundament wiedzy literackiej miał charakter eklektyczny i w znacznym stopniu wiązał się z ich prawosławną tożsamością konfesyjną.

Stefana Zanovicia umiejscowić można w kręgu zarówno filozofów, jak i skandalistów czy politycznych bądź życiowych intrygantów, na co złożyły się doświadczenia edukacyjne i twórcze oraz burzliwe koleje jego losów. Po studiach, między innymi w ośrodku padewskim, urodzony na czarnogórskim terytorium republiki św. Marka młody myśliciel i globtroter przebywał w Paryżu (gdzie ogłaszał poezje), Londynie, Marsylii, Mediolanie, Turynie, Genui, Rzymie, Neapolu. Dreźnie, Wiedniu, Berlinie, Petersburgu, Warszawie (i nawet niewielkim Słonimiu - w Polsce żył między innymi pod opieką członka konfederacji barskiej hrabiego Michała Ogińskiego, wcześniej w Dubrowniku poznawszy księcia Karola Radziwiłła), Amsterdamie (tam popełnił samobójstwo), nawiązując rozległe osobiste lub korespondencyjne znajomości także z czołowymi przedstawicielami elit intelektualnych i politycznych formatu Woltera (którego poglądy w pełni podzielał), Jeana-François Marmontela, Jeana d'Alemberta i Katarzyny Wielkiej³.

2 Por. S. Kalezić, Refleksi racionalizma u Crnoj Gori [w:] idem, Crnogorska književnost u književnoj kritici, t. III: Racionalizam, romantizam, Podgorica 2000, s. 20; M. Pantić, Književnost na tlu Crne Gore i Boke kotorske od XVI do XVIII veka, http://www.rastko.rs/rastko-cg/umjetnost/ mpantic-xvi-xviii/xviii_c.html (dostęp: 4.05.2020).

3 Por. S. Kalezić, Refleksi racionalizma u Crnoj Gori.., s. 20-21. 
Deklarując się jako sentymentalny następca Jana Jakuba Rousseau oraz korzystając z licznych zdobytych doświadczeń i kontaktów, zyskał sobie opinię przekonanego głosiciela prawd epoki i w takim też duchu interpretowana jest jego intelektualna spuścizna. W erudycyjnej syntezie poglądów cudzych i oryginalnych własnych, jaką stanowi ów dorobek pod względem merytorycznym, artystycznym (z często w nim widoczną frazą barokową) ${ }^{4}$ i genologicznym, widzieć należy bardziej zastosowanie strategii popularyzatorskiej niż pionierskie formułowanie konkretnych zasad filozofii oświecenia, w których systematycznym rozwijaniu przeszkadzał Zanoviciowi awanturniczy temperament. Znajdował on wyraz w charakterystycznym połączeniu genialności umysłu z życiowym sprytem, akademickiego opanowania z talentem uwodziciela, filozoficznego dystansu z osobowością hazardzisty i libertyna. Rodzajem programowego tekstu czarnogórskiego autora propagującego racjonalistyczny sposób poznania są opublikowane w językach francuskim i niemieckim Misli (1784, 1785), na które składają się skompilowane cytaty pochodzące z dzieł wybranych filozofów - począwszy od epoki starożytnej (Aureliusza i Kwintyliana), a skończywszy na renesansowej (Michela de Montaigne’a). Za autorskie motto uznać należy sentencję: „Nie ma niczego korzystniejszego niż wszystko wyrozumować [promozgati] i niczego szlachetniejszego od odrzucenia wszystkiego, co nie ugnie się przed światłem rozumu"`, zaś do czołowych omawianych w tekście dominant znaczeniowych należą kategorie mądrości/rozumu, religii, poznania rozwijającego się poprzez doświadczenie, wolności, tolerancji oraz sprawiedliwości rozumianej jako wartość uniwersalna. Spośród aforystycznych diagnoz stanu niespokojnego ludzkiego umysłu wiele dotyczy tu też iluzoryczności wiary w dobro, którą niszczą warunki egzystencji i fałszywe wyobrażenia. W dwóch przełożonych na kilka języków powieściach: Veliki Kastriot od Albanije (1779) oraz Šćepan Mali (1784) transponuje z kolei oświeceniowe wątki społeczne (zagadnienie szczęścia narodu powiązanego z autorytetem panującego i zacofania cywilizacyjnego wynikającego z nieodpowiednich rozwiązań ustrojowych - co ma konotacje czarnogórskie), nawiązując do własnych fascynacji osobą Skanderbega (z którym według mało wiarygodnej autobiografii łączyło go pokrewieństwo w linii żeńskiej) ${ }^{7}$ i Śćepana Małego (jego zaś tożsamość próbował sobie przywłaszczyć, znał również osobiście władykę Petara I). W jednej ze scen z pierwszego utworu albański bo-

$4 \mathrm{Na}$ temat typowo barokowych refleksów obecnych w traktatach poświęconych Polsce, zwłaszcza zaś w tomie poezji miłosnej Chansons amureuses a Gertrude de Pologne, zob. I. Čamanjska, B. Željinjski, Poljska dela Stefana Zanovića [w:] S. Kalezić, Crnogorska književnost u književnoj kritici, t. III: Racionalizam, romantizam, Podgorica 2000, s. 145-153.

5 Cyt za: S. Kalezić, Refleksi racionalizma u Crnoj Gori..., s. 22 (przekład cytatów w całym tekście D.G.).

6 Dzieło Zanovicia wydane zostało dopiero niedawno: S. Zanović, Šćepan Mali, priredili D. Kujović, M. Miljić, Podgorica, 2010.

7 Por. S. Kalezić-Djuričković, Braća Zanović kao predstavnici racionalizma na tlu crnogorskog primorja, „Matica” 2015, br. 64, s. 143, http://www.maticacrnogorska.me/files/64/06\%20sofija\%20 kalezic\%20 djurickovic.pdf (dostęp: 13.0.2019); oraz S. Kalezić, Stefan Zanović - život kao roman [w:] idem, Crnogorska književnost u književnoj kritici, t. III: Racionalizam, romantizam, Podgorica 2000, s. 128. 
hater poucza swego syna prawdami wolnego rozumu na miarę wskazówek dla oświeconego monarchy w kwestiach ustroju państwa, w drugim tekście realizuje natomiast krytyczną myśl, zgodnie z którą ,jjedynie filozof poszukuje przyczyn cudowności, nie pozwalając pokryć się cieniem". Mając w europejskim świecie literackim etykietę obieżyświata-wolterianisty, Zanović dał się też zauważyć jako autor wzorowanego na Listach perskich Monteskiusza zbioru obserwacji Turska pisma $(1766)^{9}$, nawiązujących do dramatycznej przedrozbiorowej sytuacji w Polsce - zdemoralizowanej krótkowzrocznością własnych elit. Pretendował on nawet do uzyskania tronu w Polsce przy pomocy Fryderyka Wilhelma II (proponował także swe usługi jako kandydat na przywódcę Stanów Zjednoczonych), czego świadectwem są dwa opatrzone materiałem dokumentalnym traktaty: Le destin politique de la Pologne (Politička sudbina Poljske - 1778) i L'Horoscope politique de la Pologne [...] (Politički horoskop Poljske [...] - 1778). Z każdego z nich wysnuć można na polskim przykładzie pesymistyczny wniosek - pozostawienia państwa poza obrębem oświeconej części kontynentu w przypadku zarzucenia niezbędnych w nim reform, najlepiej tak rewolucyjnych, jakie zostały przeprowadzone w Holandii czy Szwecji, a także w Rosji za rządów Piotra Wielkiego ${ }^{10}$. Zarówno w tych, jak i w innych wymienionych tekstach cechami charakterystycznymi są synkretyzm gatunkowy, liczne elementy dokumentalistyczne i dowolne traktowanie źródeł historycznych, ale wartości pozytywne stanowią w nich retoryczny rozmach oraz moc fantazji; jego pisana stylem wysokim poezja nosi również znamiona gatunkowej różnorodności, obejmując sonety, madrygały czy anakreontyki ${ }^{11}$, odnajdziemy w jej kręgu nawet dedykowany być może Polce cykl Ljubavne pjesme Gertrudi od Poljske. Wiele książek ukazywało się pod pseudonimami - często bardzo wymyślnymi, a publikacje niemal wyłącznie w obcych językach miały służyć dodaniu osobie twórcy prestiżu w szlachetnym towarzystwie, w którym się obracał.

W zupełnie innej konwencji próbował przeszczepić na glebę czarnogórską oświeceniowe argumenty reformatorskie pochodzący z plemienia Bratonožiciów (Albano-Crnogorac, jak się podpisywał) Jovan Baljević ${ }^{12}$. W obronionej w 1752 roku w Halle rozprawie doktorskiej Dissertatio philosophica de propagatione religionis armata (Filosofska disertacija o širenju religije militantnim sredstvima) ${ }^{13}$

8 Cyt. za: R. Rotković, Narativne proze Stefana Zanovića [w:] S. Kalezić, Crnogorska književnost u književnoj kritici, t. III: Racionalizam, romantizam, Podgorica 2000., s. 142.

9 Utwór wydany został dopiero w latach 90. XX wieku: S. Zanović, Turska pisma, Cetinje 1996. Niektórzy badacze skłaniają się ku opinii, że utwór ten uznać można za pierwszą czarnogórską powieść. Por. A. Radoman, Turska pisma Stjepana Zanovića kao prvi roman u crnogorskoj književnosti, „Lingua Montenegrina" 2009, br. 3, s. 355-360.

10 Szczegółowe omówienie programu zawartego w traktatach zob. I. Čamanjska, B. Željinjski, op. cit., s. 147-151.

11 Por. M. Pantić, Stjepan (Stevan) Zanović kao pjesnik [w:] S. Kalezić, Crnogorska književnost u književnoj kritici, t. III: Racionalizam, romantizam, Podgorica 2000, s. 136.

12 Jovan Steanov(ić) Baljević, znany także jako Balević, Baleović, Balović czy Bolević.

13 Rozprawa przetłumaczona na język czarnogórski została wydana w 2002 roku w obrębie monografii D.J. Martinovicia; zob. D.J. Martinović, Dr Jovan Stefanović Baljević (ili Šćepan Mali) život i rad, Podgorica 2002. 
zawarł on wiele ideowych czynników stanowiących motywy wędrowne piśmiennictwa epoki, które w najważniejszym uniwersyteckim ośrodku pietyzmu protestanckich Niemiec w rok po ukazaniu się pierwszego tomu dzieła francuskich encyklopedystów w sposób kompleksowy odzwierciedliły główne dylematy nowego podejścia do religii. Dzięki atmosferze umysłowej panującej w ważnej dla prawosławnych Słowian (także wschodnich) i Greków wszechnicy w wymienionej dysertacji znalazły się śmiałe na ów czas rozważania dotyczące wolności sumienia na tle przemian świadomości religijnej od epoki antycznej i konieczności akceptacji ludzkiej jednostki jako bytu rozumnego, w wolny i odpowiedzialny sposób godnej przyjęcia Boga - najbardziej dla niej odpowiedniego i bez przymusowego narzucania konkretnej wiary. Kontekstem rozumowania „wybierającego drogę wysokich ideałów i kształcenia" 14 Baljevicia są ponadnarodowe standardy prawodawstwa w kwestii tolerancji, zdolność człowieka do oceny przejawów dobra i zła, racjonalna i argumentacyjna podstawa refleksji o religii oraz problem narzucanego politycznego panowania nad „cudzą religią” jako niezgodnego z naturą i niemoralnego aktu - zagadnienia $\mathrm{w}$ większości zbieżne $\mathrm{z}$ cechami protestanckiego punktu widzenia. Twórca traktatu w młodości sam doświadczył w Sarajewie ocalenia z rąk duchownego przed wcieleniem do korpusu janczarów, co jednak nie nastawiło go negatywnie wobec samego islamu, a nawet nie przeszkodziło w krytyce prześladowań odszczepieńców (donatystów), jakie popierał w swych pismach św. Augustyn. Ważne jest tu też powoływanie się na autorytet filozofa francuskiego Pierre'a Bayle'a, który mimo odrzucenia ateizmu sądził, że ateistyczne społeczeństwo wcale nie musi wykonywać swych zadań gorzej od wyznaniowego ${ }^{15}$. W wydanej ponad trzydzieści lat przed rewolucją francuską i jedenaście przed Traktatem o tolerancji Woltera Filozoficznej rozprawie o szerzeniu religii za pomoca oręża wojennego są już ponadto obecne sygnały krystalizowania się pojęcia obywatelskiego społeczeństwa i odpowiedzialności jednostkowej (zamiast zbiorowej ogółu poddanych) za czyny popełnione w konflikcie religijnym, jak też diagnozy klerykalizmu, fanatyzmu, nietolerancji, przesądów i niewiedzy, z którymi należałoby podjąć walkę ${ }^{16}$. Dzieło czarnogórskiego doktora filozofii i prawa znane było i dyskutowane w kręgach zachodnioeuropejskich myślicieli, wpisując się w tradycje działań reformatorów Kościoła powszechnego stykających się z transformacją jednolitej dotychczas europejskiej wspólnoty chrześcijańskiej w wielowyznaniową. Podkreślając znaczenie kategorii etyki i rozumu w stosunkach z różnymi grupami wierzących, twórca rozprawy odsłania także demokratyczny charakter społeczności, z której pochodzi - egalitarnej czarnogórskiej zbiorowości pełnej szacunku dla sprawiedliwości i prawdy oraz stykającej się na co dzień z reprezentantami wiary katolickiej czy muzułmańskiej. W związku z tym najbardziej intrygującym szczegółem nie do końca udokumentowanej

14 B. Marinković, Beleške o zaboravljenoj tradiciji, „Savremenik” 1968, br. 10, s. 246-263, cyt. za: N. Racković, Filozofska misao u Crnoj Gori, Cetinje 1994, s. 45.

15 Por. G. Sekulović, Ideje o religiji i etici kod Jovana Baljevića i Džona Plamenca, „Matica” 2016, br. 68, s. 299.

16 Por. G. Sekulović, Jovan Baljević kao pionir moderne evropske teorije o demokratiji, „Matica” 2015, br. 62, s. 81-90. 
biografii Baljevicia jest jego powracająca w wielu pracach historiograficznych, religioznawczych i historycznoliterackich identyfikacja z samozwańczym carem Šćepanem Malim, którego działalność polityczna w kraju przyniosła wiele pozytywnych skutków wypływających z przyjęcia przedstawionych w omawianym utworze postulatów ${ }^{17}$.

Problemy państwa wszystkich obywateli oraz sprawiedliwej władzy pozostającej w dystansie od decyzyjnego ośrodka Cerkwi stanowią centralne zagadnienia w napisanym w języku rusko-słowiańskim dziele Kratki opis o Zeti i Crnoj Gori $(1774)^{18}$. Jest ono nietypowe zarówno z powodu swojego niezwykle jak na realia XVIII-wiecznej Czarnogóry postępowego przesłania społeczno-politycznego, jak i osoby autorki Kateriny Radonjić - jedynej kobiety w gronie propagatorów idei oświeceniowych. Z pewnością książka ta zawdzięcza swe powstanie specyficznym warunkom panującym na zromanizowanym wybrzeżu, gdzie znajdował się do 1830 roku konkurujący z siedzibą władyków cetińskich ośrodek władzy kotorskich gubernatorów, blisko związanych z cywilizacyjnymi wzorcami weneckimi i normami prawno-ekonomicznymi Zachodu. Echa nauki o prawie naturalnym i umowie społecznej oraz zawarta $\mathrm{w}$ tym utworze idea konstytucjonalizmu świadczą nawet - zdaniem niektórych dawniejszych badaczy piśmiennictwa czarnogórskiego - że za żeńskim pseudonimem mógł się ukrywać zarządzający tą częścią kraju guvernadur Jovan Radonjić (1748-1803) ${ }^{19}$. W ostatnim czasie przeważa jednak pogląd, iż rzeczywistą twórczynią tekstu jest właśnie jego bliska krewna, mająca bardzo dobre rozeznanie w kulisach administrowania Czarnogórą ${ }^{20}$. Jej zdaniem, ta „umiejętność władania, wojaczki oraz znajomość zasad urządzenia społeczeństwa" ${ }^{21}$ powinna uwzględniać główne cele wyzwolenia człowieka i oświecenia całego społeczeństwa, co możliwe jest tylko przy wyzwoleniu polityki z więzów myślenia mitycznego. W wykazującym liczne ideowe inspiracje traktacie autorka podąża wyraźnie śladem myśli Paula d'Holbacha o konieczności odrzucenia dedukowania religijnego i wszelkich zabobonów (jako zwolenniczka sekularyzacji państwa otwarcie krytykuje rządy władyków), jak też akcentuje niezbędność rozumowego osądu ludzkich uczynków i naukowego po-

17 Wśród badaczy czarnogórskich toczy się w ostatnich latach zażarta dyskusja na temat postaci Baljevicia. Argumenty pozwalające utożsamić go z carem Šćepanem Malim zaprezentowane w dwóch monografiach: R.V. Petrović, Šćepan Mali zagonetka je rešena, Beograd 2001 oraz we wcześniej przywoływanej książce D.J. Martinovicia (Dr Jovan Stefanović Baljević...) stanowczo w roku 2016 odrzucił Željko V. Jovanović, por. Ž.V. Jovanović, Da li su Jovan Baljević $i$ Šćepan Mali ista ličnost? (I i II dio), „Portal Analitika”, 8-9.04.2016, https://www. portalanalitika.me/clanak/225027--zeljkov-jovanovic-da-li-su-jovan-baljevic-i-scepan-mali-ista-licnost (dostęp: 10.04.2020).

18 Wydanie fototypiczne dzieła ukazało się w 1970 roku w Belgradzie: Kratki opis Zete i Crne Gore, pripremio S. Radovanović, Posebna izdanja SANU, knj. 68, Beograd 1970, wydanie krytyczne zaś wraz z przekładem z języka ruskosłowiańskiego opublikowano dopiero w 1998 roku, zob. Kratki opis o Zeti i Crnoj Gori, preveo i priredio B. Šekularac, Podgorica 1998.

19 Por. Ž.M. Andrijašević, Š. Rastoder, op. cit, s. 153.

20 Por. B. Šekularac, Uvodna riječ [w:] Kratki opis o Zeti i Crnoj Gori..., s. 41-42 oraz R. Radonjić, Sve dodje na vidjelo, „Matica” 2011, br. 46-47, http://www.maticacrnogorska.me/files/46-47/18\%20 radovan\% 20radonjic.pdf (dostęp: 15.03.2020).

${ }^{21}$ Kratki opis o Zeti i Crnoj Gori..., s. 57. 
znania rzeczywistości. Na takiej dopiero podstawie formułuje oceny czarnogórskiego społeczeństwa, w którym z podziwem dostrzega obecność cnoty heroizmu i honorowe zasady, broniąc ich jednak przed zawłaszczeniem ze strony autokratycznych i poddanych nierealnym wizjom władców. „Podążając za przykładem innych narodów europejskich” i dając podmiotowość „słabej w swojej całości masie”, osiągnąć zaś można poszanowanie w całym kraju ,praw prostych, jasnych i zrozumiałych" 22 , co miałoby oznaczać również przyjęcie za oczywiste podstaw prawa naturalnego. Pisany przystępnym stylem i wyraźnie reprezentujący nowe wartości świata zewnętrznego Kratki opis [...] miał przed wydaniem w 1970 roku dość tajemnicze dzieje jako rękopis (odkryto go przypadkiem dopiero w latach pięćdziesiątych XX wieku w Wojwodinie, wcześniej prawdopodobnie znajdował się w Wiedniu) ${ }^{23}$ i w końcu zaświadczył istnienie u schyłku XVIII stulecia umysłowego i politycznego potencjału alternatywnego wobec idei władzy teokratycznej, której nosiciele „w całym narodzie czczeni są jak prorocy”24. $\mathrm{W}$ takim ujęciu podstawowych problemów niewydolnego systemu administracji i zagrożenia wartości społecznych w Czarnogórze - przez niezgodę, chciwość, groźby panującego, brak dbałości o wspólne dobro, zaniedbanie oświaty, dewocję i zabobon - Katerina Radonjić dowodzi znakomitej orientacji w meandrach miejscowej polityki, z którą prawdopodobnie chciała zapoznać dwór austriacki w perspektywie rozmaitych nacisków rosyjskich i weneckich ${ }^{25}$. Przy okazji natomiast sporządziła na podstawie informacji z dostępnych archiwów przegląd czarnogórskich dziejów, w którym znalazło się miejsce dla obszernej prezentacji średniowiecznych państewek Duklji oraz Zety. Ze względu jednak przede wszystkim na walory spostrzeżeń z zakresu filozofii polityki, jej eklektyczny (ale z zastosowanym aparatem naukowym) utwór porównywany jest nawet z chronologicznie bliskimi manifestami światowej myśli demokratycznej - amerykańską Deklaracja niepodległości oraz francuską Deklaracja praw człowieka i obywatela ${ }^{26}$.

Raczej na marginesie głównego oświeceniowego nurtu piśmiennictwa opisanego powyżej znajdowało się kilku twórców z Boki Kotorskiej, ukształtowanych - jak Danilo Pavković czy Antun Kojović - w dużym stopniu przez zagraniczne podróże, z których wrażenia uwiecznili w swych pamiętnikach. Pavković zwiedził cały ówczesny prosvješten svijet - czyli najlepiej rozwinięte „oświecone" państwa Europy (a w sumie szesnaście krajów) i mimo krytycznego stosunku do zachodniego egocentryzmu zbliżył się na początku wieku XIX do czołowych racjonalistów francuskich ${ }^{27}$. Drugi zaś autor, ukończywszy studia teologiczne w Loreto, osiadł w Budwie i tam tworzył drobne teksty zgodnie z oświeceniową oceną ludzkiej natury i społeczeństwa, w których spontanicznie - a czasem

22 Ibid., s. 137-139.

23 Por. Kratki opis o Zeti i Crnoj Gori..., s. 27-30.

24 Ibid., s. 135.

25 Polityczno-społeczny kontekst idei prezentowanych przez Katerinę Radonjić szerzej omawia w swej monografii Radovan Radonjić - zob. idem, Politička misao u Crnoj Gori, Podgorica 2006, S. $42-52$.

26 Por. R. Radonjić, Sve dodje na vidjelo..., s. 382.

27 Por. S. Kalezić, Refleksi racionalizma u Crnoj Gori..., s. 23. 
w manierze satyrycznej - dawał wyraz w poezji (na przykład wierszu Mudroznanac na poklade) oraz prozie (utrzymane w duchu retoryki francuskiego siècle des lumières dzienniki, podkreślające wagę ,pięknych uczynków”) ${ }^{28}$. Fragmentaryczne manifestacje podobnych postaw ideowo-artystycznych dałoby się jeszcze może odnaleźć u Vuka Popovicia Risnjanina czy Lazy Popovicia Jabučanina ${ }^{29}$.

Etnarchowie z dynastii Petroviciów Njegošów rezydujący w centralnej części Czarnogóry asymilowali i praktycznie adaptowali oświeceniowe idee w sposób całkowicie odmienny. Musieli oni prowadzić pragmatyczną politykę w obliczu zacieśniającej się współpracy z Rosją oraz trwającego przez cały wiek XVIII i część XIX rozbicia terytorialnego swojego kraju, podzielonego na tereny wokół stołecznego Cetinja, zagrożoną przez Osmanów prowincję Brda i wenecką (a potem austriacką) Bokę. Już zapisana w ludowym języku epistolografia władcy-biskupa Danila Petrovicia Njegoša (1670-1735) pełna jest zdroworozsądkowych, wręcz przyziemnych konstatacji na temat różnych świeckich korzyści politycznych - na przykład związanych z decyzjami o podjęciu wojny przeciw Turcji za namową Piotra Wielkiego czy tępieniem ,zdrady, przekupstwa i grabieży”30 będących codziennością rozdartego i zatomizowanego narodu. Równocześnie Danilo odwołuje się do społeczno-etycznych rad znajdowanych w przywożonych z zagranicy książkach i także z tych ,źródeł mądrości” czerpie swe argumenty dla obrony praw kobiet do sprawiedliwego osądu ich win oraz dla afirmacji wartości rodzinnych. Takie przenikliwe widzenie wśród poddanych odpowiedniego porządku ich doskonałości powodowało, że wielu badaczy kwalifikowało tego piszącego hierarchę jako zwolennika autentycznego życia we wspólnocie czy przedoświeceniowego moralistę ${ }^{31}$.

Kolejny władyka z cetińskiego rodu, Sava Petrović (1702-1782), zajmuje ważne miejsce jako etyczny arbiter trzymający się zasady trzeźwej analizy konkretnych uczynków własnych podopiecznych, których zwykł był oceniać według jaskrawych przeciwstawień dobra i zła. W jego zróżnicowanych pismach obecne jest kategoryczne potępienie wszystkich działań ludzkich naruszających stan pokoju, uznawany za najbardziej pożądany przez oświecony i doświadczony umysł postrzegający rzeczywistość w sposób rozumny, spoglądając na świat „otwartymi oczami” (otvorenijeh očiju). W sferze tak rozumianego racjonalizmu pozostają też jego plany rozwoju szkolnictwa i kilkukrotne tolerancyjne wypowiedzi kierowane do rodzimych innowierców (na przykład apele do katolików o niepogłębianie sporów z prawosławnymi czy uwagi o dwóch obrządkach jako jednakowo uświęconych i miłych Bogu) ${ }^{32}$.

Vasilije Petrović Njegoš (1709-1766) w jeszcze większej mierze darzył zaufaniem mądrość zapisaną w księgach, czemu dał wyraz w dziele historiograficznym Istorija o Crnoj Gori (1753/1754), mimo deklarowanej wiary w poznawczą

28 Ibid., s. 28-29.

29 Por. M. Pantić, Književnost na tlu Crne Gore i Boke kotorske....

30 „Jedan je idol preljubodejanije, drugi idol srebroljubije, treći idol grabljenije i krvoprolitije” cyt. za: S. Kalezić, Refleksi racionalizma..., s. 15.

31 Ibid.

32 Por. ibid., s. 16-17. 
moc rozumu będącego jeszcze syntezą bezkrytyczną i niedokładną, w dodatku pełną leksykalno-gramatycznych rusycyzmów. Wiedza książkowa w nim wykorzystana zastosowana została jednak do udowodnienia, że kolektywną wolność i tożsamość Czarnogórców można przedstawić w wymiarze pewnego dziejowego continuum. Prócz tego władyce przyświecała idea kształcenia i służby młodzieży męskiej w Rosji - w tej i innych kwestiach korespondował z hrabią Aleksiejem Bestużewem-Riuminem, któremu zwierzał się między innymi z zatroskania stanem społeczeństwa w prowincjach północnych, gdzie niepokoił go brak ksiąg u duchowieństwa i „mgła niewiedzy” prostego ludu. Pragnął też utworzyć szkołę z programem filozoficzno-filologicznym, w której kształciliby się także synowie Kościoła rzymskiego ${ }^{33}$.

Instrumentalne traktowanie prawosławia w sprawowaniu władzy ziemskiej, ale i wychowawczo-emancypacyjne nastawienie do własnego narodu odbiło się przede wszystkim na aktywności najbardziej znanego przedstawiciela formacji oświeceniowej z kręgu władyków - Petara I Petrovicia Njegoša (1748-1830, po śmierci kanonizowanego). Posiadał on wielki dar perswazji, a zarazem chłonny umysł czerpiący natchnienie $\mathrm{z}$ własnej bogatej biblioteki i zdolności literackie zamanifestowane $\mathrm{w}$ cyklu pisanych przez całe życie posłań do plemion $(\text { Poslanice })^{34}$. Były one tworzone z intencją przeciwstawienia się surowym i spoganizowanym obyczajom czarnogórskich górali, w których moralnym oświeceniu i integracji upatrywał główne zadanie sprawującego rządy przywódcy. Teksty te jaskrawo pokazują podporządkowanie celów religijnych świeckim, ponieważ na niezgodę, prymitywizm i przesąd mógł reagować wyłącznie powołaniem się na własny autorytet administracyjno-kościelny, nie posiadając żadnych prawnych środków przymusu poza klątwą, pozbawieniem sakramentów i słowem pisanym. W takich warunkach wezwania do utrzymania elementarnych standardów moralnych w sposób racjonalny uzasadniały racje panującego, a poddani musieli dobrowolnie korygować rozumienie własnej godności. Niewdzięczną rolę głosiciela ewangelicznych pouczeń w środowisku „ludzi natury” Petar I realizował z poświęceniem, wyposażając swe typowo świeckie przekazy w konkretne przemawiające do wyobraźni exempla, nie kryjąc oburzenia z powodu niechrześcijańskich postępków i piętnując ich konkretnych sprawców z poszczególnych rywalizujących z sobą plemion. Taka - edukacyjna również - postawa sprzyjała zrozumieniu interesu własnego ( $z$ a vašu korist) jako sprzężonego z kolektywnym oraz implikowała sankcje w przypadku szkodliwych form egoizmu, samowoli i chytrości „zdrajców pozbawionych rozumu" ${ }^{35}$. Ucywilizowanie i instytucjonalizacja życia plemiennego w sytuacji braku systemu oświaty były wyzwaniem na miarę stworzenia całkiem nowego wzorca osobowego człowieka wychodzącego ze stanu natury i również w innych krajach południowosłowiańskich, w bardziej sprzyjających warunkach, podobna tendencja charakteryzowała całą wczesną re-

33 Por. R. Radonjić, Politička misao..., s. 31. Zob. także S. Kalezić, Refleksi racionalizma..., s. $18-20$.

34 Zob. Petar I Petrović, Poslanice, Cetinje 1993.

35 Ibid. (Poslanica mitropolita Petra I Petrovića Crnogorcima i Brdjanima od 6. oktobra 1825. godine), s. 242-243. 
ligijną fazę „epoki rozumu”. Aspekt chrześcijański miał więc dla władyki także sens wyzwolenia z ciemnoty, pogańskich zabobonów i czarów oraz wszelkiej nierozumności działań (bezumije), które szkodziły potencjalnie szlachetnym osobowościom. Biblia stanowiła tu autorytet, na który autor posłań powoływał się na równi z innymi tekstami wzmacniającymi argumentację, a ideały zgody, hierarchii społecznej, wierności czy zdolności do kompromisu były wyprowadzane z ludowych pieśni bohaterskich. Utrzymany w takiej konwencji przekaz przystępnego piśmiennictwa dydaktycznego ukazującego siłę ,prawdy” uosabianej przez „mądrych ludzi” (pokazuje to także wiersz Poučenje u stihovima) ${ }^{36}$ reprezentuje podobny typ społecznej pedagogiki jak u czołowej postaci oświecenia serbskiego Dositeja Obradovicia. Trzeba też przypomnieć o prawodawczej roli Petara I, nalegającego bezustannie na zawarcie międzyplemiennej zgody (typu umowy społecznej) mającej regulować wzajemne stosunki dla korzyści wynikających z „dobrego sąsiedztwa” - co widzimy na przykład w posłaniu do plemienia Njegušów ${ }^{37}$. Nieugiętą naturę polityczną, wiarę w moc sprawczą słowa i specyficzne pojmowanie dualizmu porządków religijnego i laickiego przejął po swym stryju Petar II Petrović Njegoš (1813-1851), który do pewnego stopnia twórczo zasymilował w swych dziełach idee oświeceniowe, chociaż jego poezja sytuuje go już przede wszystkim w epoce romantycznej. W myśli tego władyki-poety obecne będą co prawda racjonalistyczne pierwiastki, lecz jako całość należy ją raczej określić jako eklektyczną - syntezującą różne filozoficzne nurty, a przede wszystkim łączącą ludową tradycję mityczną z neochrześcijańską, synkretyczną odmianą prawosławia. Obradović natomiast, „Pierwszy Oświeciciel Narodu”, stanie się dla niego nawet heretyckim zagrożeniem, którego „bezbożne” utwory już w warunkach zmiany modelu kulturowego w sąsiedniej Serbii na ludowo-patriarchalny - zakazał ponoć w Czarnogórze publikowaćs ${ }^{3}$.

Poszukiwania odpowiedniego do miejscowych warunków sposobu wyrażenia paradygmatu oświeceniowych pojęć i wartości doprowadziły w czarnogórskiej rzeczywistości do zarysowania się kilku autorskich propozycji, nie w pełni jednak oddających wszystkie znaczenia zachodnioeuropejskiego, a nawet serbskiego czy rosyjskiego wzorca. Jak się przekonaliśmy, w niewielkiej południowosłowiańskiej literaturze nie wykształcił się żaden spójny program tego typu, który mógłby spotkać się z szerokim odbiorem, polemiką czy choćby zwykłym odnotowaniem w kraju rozbitym terytorialnie i zmagającym się z problemami zewnętrznymi i wewnętrznymi. Mimo tego zaistniało w niej kilka zjawisk charakterystycznych, mogących służyć za przykład interesującej adaptacji prądów umysłowych ogarniających w XVIII wieku całą Europę, niezależnie od pozornej izolacji pewnych jej regionów: wszechstronna twórczość Stefana Zanovicia erudycyjnie traktująca wiele wątków filozoficznych ukazywanych w blasku ,światła rozumu” (ale i korespondujących z oryginalnością jego postaci), prekursorskie dzieło Jovana

36 Por. Sveti Petar Cetinjski, Poučenje u stihovima, https://www.rastko.rs/bogoslovlje/sv_petar_ cetinjski.html\# poucenje (dostęp: 5.05.2020).

37 Por. Petar I Petrović, Poslanice (Njegušima)..., s. 255-257.

38 Por. D. Gil, Prawostawie. Historia. Naród. Miejsce kultury duchowej w serbskiej tradycji i wspótczesności, Kraków 2005, s. 123. 
Baljevicia z pogranicza filozofii religii i prawa o szerokim oddźwięku międzynarodowym; oryginalna diagnoza czarnogórskiego życia politycznego i społecznego autorstwa związanej ze zokcydentalizowanym adriatyckim wybrzeżem Kateriny Radonjić oraz całokształt literackich dokonań władyków z narodowej dynastii - na czele z moralnym wychowawcą plemiennej Czarnogóry Petarem I. Każdy z tych fenomenów na swój sposób świadczy o indywidualnej transformacji kategorii literacko-filozoficznych europejskiego oświecenia w środowisku będącym wówczas dla wielu obserwatorów zewnętrznych obszarem bardzo słabo znanym, dla większości z nich stanowiących może wręcz prawdziwą terra incognita.

\section{Bibliografia}

Andrijašević Ž.M., Rastoder Š., Istorija Crne Gore od najstarijih vremena do 2003, Podgorica 2006.

Čamanjska I., Željinjski B., Poljska dela Stefana Zanovića [w:] S. Kalezić, Crnogorska književnost u književnoj kritici, t. III: Racionalizam, romantizam, Podgorica 2000, s. $145-153$.

Gil D., Dylematy identyfikacyjne w obrębie serbsko-czarnogórskiej kulturosfery. Dawne i wspótczesne modele (auto)refleksji, Kraków 2019.

Gil D., Prawostawie. Historia. Naród. Miejsce kultury duchowej w serbskiej tradycji i wspótczesności, Kraków 2005.

Jovanović Ž.V., Da li su Jovan Baljević i Šćepan Mali ista ličnost? (I i II dio), „Portal Analitika", 8-9.04.2016, https://www. portalanalitika.me/clanak/225027-zeljko-v-jovanovic-da-li-su-jovan-baljevic-i-scepan-mali-ista-licnost (dostęp: 10.04.2020).

Kalezić S., Refleksi racionalizma u Crnoj Gori [w:] S. Kalezić, Crnogorska književnost u književnoj kritici, t. III: Racionalizam, romantizam, Podgorica 2000, s. 13-29.

Kalezić S., Stefan Zanović - Život kao roman [w:] S. Kalezić, Crnogorska književnost u književnoj kritici, t. III: Racionalizam, romantizam, Podgorica 2000, s. 125-132.

Kalezić-Djuričković S., Braća Zanović kao predstavnici racionalizma na tlu crnogorskog primorja, „Matica” 2015, br. 64, http://www.maticacrnogorska.me/ files/64/06\%20sofija \%20kalezic\%20 djurickovic.pdf (dostęp: 13.07.2019).

Kratki opis o Zeti i Crnoj Gori, preveo i priredio B. Šekularac, Podgorica 1998.

Kratki opis Zete i Crne Gore, pripremio S. Radovanović, Posebna izdanja SANU, knj. 68, Beograd 1970.

Marinković B., Beleške o zaboravljenoj tradiciji, „Savremenik” 1968, br. 10, s. 246263.

Martinović D.J., Dr Jovan Stefanović Baljević (ili Šćepan Mali) život i rad, Podgorica 2002.

Pantić M., Književnost na tlu Crne Gore i Boke kotorske od XVI do XVIII veka, http://www.rastko.rs/rastko-cg/umjetnost/mpantic-xvi-xviii/xvii__c.html (dostęp: 4.05.2020).

Pantić M., Stjepan (Stevan) Zanović kao pjesnik [w:] S. Kalezić, Crnogorska književnost u književnoj kritici, t. III: Racionalizam, romantizam, Podgorica 2000, s. $133-138$. 
Pejović Dj. D., Crna Gora u doba Petra I i Petra II, Beograd 1981.

Petar I Petrović, Poslanice, Cetinje 1993.

Petrović R.V., Śćepan Mali zagonetka je rešena, Beograd 2001.

Racković N., Filozofska misao u Crnoj Gori, Cetinje 1994.

Radoman A., Turska pisma Stjepana Zanovića kao prvi roman u crnogorskoj književnosti, „Lingua Montenegrina” 2009, br. 3, s. 355-360.

Radonjić R., Crnogorska retorika, Podgorica 2011.

Radonjić R., Politička misao u Crnoj Gori, Podgorica 2006.

Radonjić R., Sve dodje na vidjelo, „Matica” 2011, br. 46-47, http://www.maticacrnogorska.me/files/46-47/18\%20radovan\%20radonjic.pdf (dostęp: 15.03.2020).

Rotković R., Narativne proze Stefana Zanovića [w:] S. Kalezić, Crnogorska književnost u književnoj kritici, t. III: Racionalizam, romantizam, Podgorica 2000, s. 139-144.

Sekulović G., Ideje o religiji i etici kod Jovana Baljevića i Džona Plamenca, „Matica” 2016, br. 68, s. 283-314.

Sekulović G., Jovan Baljević kao pionir moderne evropske teorije o demokratiji, „Matica” 2015, br. 62, s. 81-90.

Sveti Petar Cetinjski, Poučenje u stihovima, https://www.rastko.rs/bogoslovlje/sv_ petar_cetinjski.html\# poucenje (dostęp: 5.05.2020).

Zanović S., Śćepan Mali, priredili D. Kujović, M. Miljić, Podgorica 2010.

Zanović, S. Turska pisma, Cetinje 1996. 
